\title{
Detection Of Blood Parasites In Cattle In Kutalimbaru Subdistrict, Deli Serdang Regency, North Sumatera
}

\author{
Mudhita Z. Ritonga ${ }^{1 *}$, Andhika Putra $^{2}$, Agun Prastia ${ }^{2}$, Firdaus Nasution ${ }^{2}$, and Risdawati Br Ginting ${ }^{2}$ \\ ${ }^{1}$ Faculty of Veterinary Medicine, Universitas Syiah Kuala, Aceh, Indonesia \\ ${ }^{2}$ Animal Husbandry Department, Faculty of Science and Technology, Universitas Pembangunan Panca Budi, Medan, Indonesia
}

\begin{abstract}
The aim of this research was to identify and to find out the prevalence of blood parasites in cattle in Kutalimbaru Subdistrict, Deli Serdang Regency. This research was conducted in Kutalimbaru Subdistrict, Deli Serdang Regency from December 2018 to February 2019. Normal/healthy cattle of different breeds were randomly selected from five locations, namely Sei Mencirim village, Sawit Rejo village, Silebo-lebo village, Sampe Cita village and Pasar X village. A total of 150 blood samples were collected for blood smears. Diagnostic techniques were tested using Giemsa's staining technique. The blood parasites were then identified and their prevalence was determined. The results showed that one species of blood parasite was successfully identified, all belonging to the blood parasite, namely, Theileria sp. with a prevalence of $33 \%$. In addition, there were no species of blood parasite from the Anaplasma, Trypanosoma, and Babesia. This study suggests that theileriosis is spreading to even the other region in North Sumatera. To reduce the infection, follow up surveys of the blood parasites of the livestock, assess their distribution and infection rates of possible vectors are recommended and plans control measures against should be focused on reducing transmission to highly susceptible animal species.
\end{abstract}

Keywords: blood parasite, cattle, Kutalimbaru, North Sumatera.

\section{Introduction}

Community interest in raising cattle has increased every year. The key to success in efforts to increase cattle productivity is the health of cattle itself [1]. Efforts to develop livestock populations, especially cattle, require measures to control disease, namely preventive measures for the emergence of pathogenesis from disease agents into their host [2]. One of the livestock diseases that is quite important and endemic is blood parasites because the disease can cause losses in the form of stunted growth, weight loss, decreased work power, decreased reproductive power [3] decreased milk production, and abortion [4].

Animal diseases originating from blood parasites are Babesiosis, Theileriosis, Anaplasmosis and Trypanosoma [2]. Cases of disease caused by blood parasites are generally acute but sometimes can cause death in infected animals [5]. Blood parasites are endemic diseases, especially in the tropics and sub-tropics throughout the world. The spread of blood parasitic diseases is very dependent on the condition of livestock (host), disease agents, vectors and the environment, including geographical conditions, weather climate, socio-cultural and socioeconomic areas in the area.

Kutalimbaru District is one of the areas of livestock population distribution in Deli Serdang Regency which has the potential to be developed in meeting the needs of meat and milk by looking at the increase in livestock population that is increasing every year. From the data of the Central Statistics Agency (BPS) in Deli Serdang Regency in 2016, the population of cattle in the District of Kutalimbaru reached 3,155 heads [6]. The area of land which is sufficient for abundant forage and the utilization of plantation waste which is very supportive is an opportunity for the development of cattle business. Based on this, researchers are interested in examining how much the prevalence of blood parasitic diseases in cattle in the Kutalimbaru District Deli Serdang Regency. The purpose of this study was to identify blood parasites in cattle in Kutalimbaru District, Deli Serdang Regency.

\section{Materials and Methods}

This research was conducted in Kutalimbaru District, Deli Serdang Regency, North Sumatra Province. This research starts from December 2018 until February 2019. There are various ways to make preparation. Making preparations is an effort to facilitate the observation of a material. Smears are preparations made using liquid substances. The function of making smears preparations is to observe cells in body fluids, for example in the blood.

The method of blood sampling is used in this study by using thin blood ulcer preparations. The method for making thin blood cloth preparations are: Blood sample collection is done through a jugular vein in a cow's neck with hair shaving around the ventral neck first if necessary. blood vessels dammed in $1 / 3$ distal neck. After

Corresponding author: ritongamz@unsyiah.ac.id 
the blood is blocked the neck is rubbed with cotton soaked in alcohol, its purpose is to disinfect. The sterile syringe is inserted at an angle of $30^{\circ} \mathrm{C}$ towards the blood vessel with the needle hole facing up. After the needle is inserted, the aspiration is carried out to draw the needed blood. If the blood is not sucked, it means that the needle has not entered the blood vessel. After the blood comes out of the vein, a thin ulcer preparation is made on the glass object by dripping a drop of blood on the tip of the glass object then place one end of the glass cover and make an angle of 30 then touch the drop of blood so that the blood flows following the bottom of the glass cover then push the glass cover rather quickly towards the front along the surface of the glass object then dry the blood smear.

The dried blood preparations are then fixed with methanol for 3-5 minutes after that they are given a label containing information on the cow's name, date of collection and other records deemed necessary after storing dry in the preparation box for laboratory examination. Examination of blood protozoa using 1000 times magnification [7]. The results obtained are then documented using a digital camera. Primary data were obtained from observations and examination results of the Medan Veterinary Institute sample of North Sumatra Province. Secondary data were obtained from related research and references or literature relevant to the research conducted. The data analysis used in this research is descriptive statistical analysis. Calculation of the prevalence of blood parasitic diseases using the following formula [8].

\section{Results and Discussion}

The location of this research was conducted in Kutalimbaru District, Deli Serdang Regency. Large land in this sub-district is used for agriculture and animal husbandry, land used for agriculture is usually planted with crops and livestock which are widely cultivated are cattle.

Based on the observations of researchers in the District, management in the maintenance of cattle in Kutallimbaru District Deli Serdang Regency appears to be unfavorable. Where the condition of the community farm pens in Kecamatan is less concerned with the health of livestock raised by the local community and many cattle being herded. The condition of the cage in terms of cleanliness is not directly proportional to the system that the researchers did, the sewage disposal system in the community farms dispose of their livestock manure waste next to the cage and feed provided in the form of weeds which are not infrequently adjacent to the waste itself.

The results of research conducted in Kutalimbaru District Deli Serdang Regency were found to be blood parasites that infected cattle as many as 33 samples from 100 samples of cow blood taken. It can be seen that from 33 blood samples tested the entire blood sample was positive Theileria sp.

From the results of research and laboratory test results of the four blood parasitic diseases Babesiosis,
Theileriosis, Anaplasmosis, and Trypanosoma found blood parasitic diseases, namely Theileriosis as much as $33 \%$ which infects cattle in Kutalimbaru District Deli Serdang Regency. Theileriosis is an acute and contagious blood disease caused by Theileria sp. Theleria sp. Infection causes weight loss, fever, bloody diarrhea, and swollen lymph glands. Parasites that cause proliferation in lymph cells, in these cells are formed called "Koch plasma balls" [9].

While in general, the risk factors that show that cows are exposed to blood parasites are the experience of breeders for less than 2 years, part-time typology, one feedlot for 2 head of livestock or more limited water availability, never bathe the cow, have never done vector control, no sewage shelters, fresh grass feeding systems that are direct without withering first, and no knowledge about disease. Apart from these factors, climate and rainfall factors also influence the emergence of blood parasitic disease infections [10].

Farms carried out as a sideline business and cattle that are herded are more susceptible to the occurrence of blood parasitic diseases, because breeders have limited time to clean cages and observe the health status of animals due to other major activities. Based on the analysis it is also known that the cage with a separate feedlot is associated with the incidence of Theileriosis because it will facilitate the transmission of disease from infected cattle to other livestock nearby. Environmental factors such as climate and high humidity play an important role in this disease because they trigger the development of vectors. In subtropical regions, adult tick populations increase in summer and spring, while larvae and nymph pupils increase in fall. As for the tropics, tick populations increase at the end of summer and peak at times of high rainfall. The existence of this tick is closely related to the high cases of Theileriosis in an area.

Theileriosis blood parasite control such as the Theileria sp vaccine has been developed from living pyrolasma that is inside red blood cells, but this vaccine is no longer recommended because it has the potential to spread Theileriosis more widely. At present, two vaccine candidates are being developed, namely the recombinant p32 protein vaccine and synthetic peptide. Both can produce low parasitemia status and reduce the severity of clinical symptoms. The success of treatment is largely determined by the time of administration, namely the onset of clinical symptoms. Generally, the method of preventing Theileriosis is the treatment of sensitive animals. Prevention of theileriosis can be done by reducing the vector population, through dipping, enclosure sanitation, providing repellants and doing good maintenance management. While the strategic control of Theileriosis can be done by eradicating the ticks in the integrated system.

Study of Blood Parasite Disease in Beef Cattle in Dera Ismail Khan, Khyber Pakhtunkhwa Province, Pakistan showed $14.32 \% \quad(55 / 384)$ prevalence of Theileria. [11]. The prevalence microscopic examination of blood smears revealed $27.2 \%$ (82) overall prevalence of theileriosis. The highest prevalence was found in rainy season with a prevalence rate $45.4 \%$ [12]. 
Prevalence of Theileria spp was 7.3\% in dairy cattle in Nyala, South Darfur State, Sudan [13]. Naturally, Theileriosis is transmitted stage-to-stage by ticks without transovarial transmission because these parasites cannot live in ticks for more than one time (Optional) [14]. Prevention of cases of blood parasitic disease infections can be done with continuous vector control and eradication program in Kutalimbaru District, Deli Serdang Regency.

A research result base on PCR Duplex Analysis showed that thirty out of 100 samples were selected for single PCR analysis based on parasitic type and parasitemia level consisting of 5 positive samples of babesia $\mathrm{sp}, 15$ positive samples of Theileria $\mathrm{sp}$, and 10 negative samples of blood parasites to be continued at the single PCR stage [15]. Study of Incidence of theileriosis in cattles and buffaloes during rainy season in eight region of Indore District (M.P.) showed The prevalence of T. annulata was recorded higher in cattle's (51.92\%) [16]. Out of 150 cattle screened, 35 (23.33\%) were found to be positive for Tropical theileriosis in Chhattisgarh State [17].

\section{Conclusion}

This study suggests that theileriosis is spreading to even the other region in North Sumatera. To reduce the infection, follow up surveys of the blood parasites of the livestock, assess their distribution and infection rates of possible vectors are recommended and plans control measures against should be focused on reducing transmission to highly susceptible animal species.

\section{Acknowledgments}

The authors would like to thankful to Animal Husbandry Departement of The Faculty of Science and Technology, Universitas Pembangunan Panca Budi, Medan, North Sumatera Indonesia for study and publish the data.

\section{References}

1. Kertawirawan IPA, Yasa IMRY, et al.: Efektivitas Penggunaan Ivermectin Untuk Pengendalian Parasit Cacing pada Usaha TanI Penggemukan Sapi Bali. 2012. Prosiding Seminar Nasional Teknologi Fakultas Keguruan dan Ilmu Pendidikan Universitas Kristen Satya Wacana, Sligata.

2. Bilgic HB, Karagenc $\mathrm{T}$, et al. : Development of a Multiplex PCR assay for simultaneous detection of Theileria annulata, Babesia bovis and Anaplasma marginalein cattle. Exp Parasitol. 2013;133(2):222-229.

3. Subronto : Ilmu Penyakit Ternak 2 (mamalia) Manajemen Kesehatan Ternak Paratitisme Gastrointestinal dan Penyakit Metabolisme. Yogyakarta : Gadjah Mada University Press. 2007.
4. Kocan Katherine M, de la Fuente J, et al. : Anaplasma Marginale. Vet. Parasitol. 2004; S285-2300.

5. Soulsby EJL, Lmints : Arthopodsn Protozoa of domesticated animals. Ed ke-7. England (UK): Beailliere Tindal. 1982.

6. Badan Pusat Statistik : Statistika peternakan Kecamatan Kutalimbaru. Kecamatan Kutalimbaru (Id): BPS. 2016.

7. Dirjen Peternakan dan Kesehatan Hewan : Manual Penyakit Hewan Mamalia. Subdit Pengamatan Penyakit Hewan. Dirjen Pertanian dan Keswan Republik Indonesia. Jakarta. 2012

8. Budiharta S : Kapita Selekta Epidemiologi Veteriner. Bagian Kesehatan Masyarakat Veteriner, Fakultas Kedokteran Hewan, Universitas Gadjah Mada. 2002.

9. Ressang AA : Patologi Khusus Veteriner. Bali.1984.

10. Sujarwo : Berkah Periode Iklim yang Bervariasi Menjadikan Sulawesi Selatan Sebagai Lumbung Padi Nasional. Kasubid Pelayanan Jasa BBMKG Wilayah IV Makassar. 2014.

11. Khanb A, Ashfaq K, et al. : Bovine Theileriosis: Prevalence, Estimation of Hematological Profile and Chemotherapy in Cattle in Dera Ismail Khan, Khyber Pakhtunkhwa Province, Pakistan. American Scientific Research Journal for Engineering, Technology, and Sciences (ASRJETS). 2017; 32(1): 8-17.

12. Kohli S, Atheya UK,T hapliyal A : Prevalence Of Theileriosis in Cross-Breed Cattle: Its Detection Through Blood Smear Examination And Polymerase Chain Reaction In Dehradun District, Uttarakhand, India. Veterinary World. 2014; 7(3): 168-1711.

13. Ismail A, Abaker, Diaeldin A, et al. : Prevalence of Theileria annulata in dairy cattle in Nyala, South Darfur State, Sudan. Veterinary World. 10(12): 14751480.

14. Siegel S, Howert E, Leroy BR : East coast Fever (Theileria parva)-A Review. Veterinary Clinical Pathology Clerkship Program. Department of Pathology, College of Veterinary Medicine. University of Geo Athens. 2006.

15. Akbari RA, Tiuria R, Wardhana WA, et al. : Deteksi Parasit Darah pada Sapi Perah Berdasarkan Analisis PCR Duplex. Acta Veterinaria Indonesiana. 2018. Vol. 6, No. 2: 48-55.

16. Waskel S, Usha: Incidence of theileriosis in cattles and buffaloes during rainy season. Euro. J. Exp. Bio. 2015; 5(8):71-73.

17. Naik BS, SK Maiti SK, Raghuvanshi PDS: Pevalence of Tropical Theileriosis in Cattle in Chhattisgarh State. Journal of Animal Research: 2016; 6 (6):1043-1045. 